\title{
The 'Internationalisation Agenda' and the Rise of the Chinese University: Towards the Inevitable Erosion of Academic Freedom?
}

The production of knowledge has always been a boundary-crossing endeavour. Universities are typically one of society's most 'global' institutions and academics have tended to be cosmopolitan citizens (Teichler, 2004: 8). Nevertheless, the international dimension of university activity has dramatically increased over the last thirty years, as globalisation has intensified the means through which universities around the world may communicate, collaborate and compete with one another. Thus, what has come to be known in Britain as the 'internationalisation agenda' has become an important strategy for the co-ordination of education and knowledge production in this interconnected environment. Materially driven by national economic imperatives and discursively sustained by global ranking tables and scholarly journals' impact factors, processes of internationalisation unwittingly universalise not only the form and structure of the Euro-American university, but also Euro-American epistemologies and ways of knowing (Chakrabarty, 2000: 5). ${ }^{1}$ Universities that deviate from this model perform poorly on these Western-centric indicators of excellence and are erased from the global landscape of higher education (Yang, 2014).

The central contention of this essay is that, in the context of contemporary internationalising trends, whether one promotes approaches to knowledge production dominant in Euro-American universities or seeks to diversify or decolonise international research partnerships, the result is a reduction of epistemic pluralism in global academia. ${ }^{2}$ This is due to a tension within the logic of the internationalisation agenda: UK universities are premised upon forms of knowledge production which consider that 'professors and students must be free to pursue knowledge wherever it leads and to publish their work freely without fear of sanction by either academic of external authority' (Altbach, 2015: 6), yet partnerships are growing with universities premised on rather different, non-liberal and, perhaps, incommensurable values. ${ }^{3}$ Therefore, in advancing the internationalisation agenda in nonliberal environments, UK-based scholars may find themselves caught between a rock and a hard place: either legitimising and sustaining the subjection of knowledge production to the state on the one hand, or engaging in a form of epistemological colonialism by demanding adherence to 'our values' on the other. If Levine and McCourt (2018: 93) are right to argue that the pluralism underlying the study of politics in Western universities necessarily entails 'epistemological scepticism' insofar as 'no single knowledge system can ever possess the whole truth, at least as this applies to political matters' then Western-based scholars must be open to decentring the ways of knowing dominant in Western universities. But what happens when, in so doing, we open the door to challenges to that very pluralism? To recall Isaiah Berlin's famous metaphor, it appears that the internationalisation agenda is driving scholars to speak the language of the fox, a pluralist who knows many different things, while our epistemic practices remain associated with the hedgehog, a monist who knows one big thing (Berlin, 2013).

In what follows below, I consider this tension using the example of the growing influence of China as a non-liberal actor in global higher education. I locate its differing epistemological approaches in their historical and cultural contexts, demonstrating that social science knowledge production in the Chinese university is shaped by the triple, mutually reinforcing logics of its Confucian heritage, the increasing governmental control of the public sphere and the rapid economic development of the university sector. The result is that social science knowledge performs a very different, arguably incommensurable, function in both locales: while the study of social science in the Western university has maintained a relatively independent, critical space in relation to state power, in Chinese universities it has endured tense relations with the Chinese government in its short history and continues to be subject to close government scrutiny. Existing theoretical lenses, I argue, can do little to overcome this problem of epistemological incommensurability. The liberal approach broadens the 
space in which a diversity of epistemological standpoints may be articulated, but fails to provide insight into the historic power dimensions that have shaped - and continue to shape - their interaction. Decolonial scholars argue that the liberal approach is insufficient because epistemology is necessarily socially and culturally embedded (see Barnes and Bloor, 1982: 27), and to present various forms of knowledge as different but equal is in itself a liberal move (Santos, 2014). However, much of the decolonial literature assumes that 'provincialising' European forms of rationality in order to give voice to subaltern ways of knowing is an inherently emancipatory act (Santos, 2014; Dennis, 2018: 200). Yet, as discussed below, some of these ways of knowing are oppressive, hierarchic, and run counter to an emancipatory project.

The motivation for this theoretical discussion is rooted in my own academic biography. Between 2015 and 2017, I spent three semesters working as a Lecturer at a provincial university in Xi'an, Shaanxi Province, and further three months as a Research Fellow at a prestigious university with a global reputation in Shanghai in spring 2017. During this time, I sought to engage as fully as possible with Chinese academia, presenting my work at Chinese conferences, publishing research in Chinese journals and co-writing papers with authors based at Chinese institutions for publication in journals based in the West. However, I was repeatedly confronted with differing practices of knowledge production that left me feeling unsure whether social science truth claims produced in a Chinese university could be considered as valid as those produced in a British university, not least the fact that the production of social science research was subject to close monitoring by Communist Party ideological auditors inside the university. Indeed, I was subjected to practices associated with censorship in both universities, including the unexplained rejection of a journal article, the sudden withdrawal of a colleague from a research partnership and the public silencing of my presentation during a conference. While I found these practices disconcerting, I was plagued by the question of whether I was merely socialised into dominant 'Western' epistemological traditions of critique and pluralism, and whether my belief in its superiority was evidence of tacit colonial thinking. To put it bluntly: can a commitment to epistemic pluralism entertain the existence of an epistemological approach that seeks to extinguish that very pluralism? The following discussion represents my attempt at reconciling these two logics. While the answer to the above mentioned question is, in all likelihood, 'no', I conclude that, given the role of social context in shaping knowledge production, which itself is constantly evolving, we must adopt a critical perspective on our own academic culture and reveal the particularist experiences that have bred the claims to universalism underpinning the liberal project. Only by provinicialising our experience can we begin to build bridges across epistemological divides.

One important caveat is necessary before commencing the discussion. While this essay is focussed on China as the most significant illiberal actor in global higher education, increasing attempts to shape and control social and political research are not limited to China or, indeed, the 'non-West' (see Traianou, 2015; Nelson, 2011; Said, 1994). The commercialisation of global academia means that knowledge produced in universities around the world is increasingly shaped by economic imperatives, such as funding calls, student recruitment numbers and private investments, much of which is coordinated by national governments, liberal and illiberal alike. ${ }^{4}$ Furthermore, Chinese scholarship has contributed tremendously to global scientific development and the following discussion is not intended to suggest otherwise. Instead, I seek to utilise the example of the contemporary Chinese case, whose government is explicitly positioning itself against 'Western' epistemological norms, in order to illustrate the ways in which current incarnations of the internationalisation agenda may facilitate a reduction in global epistemic pluralism.

The essay is divided into four sections. I begin with a discussion of the internationalisation agenda and argue that the process of creating international research partnerships tends to rely on a commitment to a single, hegemonic epistemology. The second section details China's rise in the global academic rankings and the concomitant clash of epistemological values between the Chinese government and 
Western academic institutions. The third section explores three factors which shape the social context of knowledge production in China, namely its Confucian heritage, political environment and economic development. The fourth section compares liberal and decolonial approaches to the problem of how one might decentre European epistemology and concludes that neither approach can prevent the rise of hegemonic, anti-pluralistic forces in global academia while the economically driven internationalisation agenda remains the driving force for international collaboration.

\section{Internationalisation as Epistemic Colonialism}

The concept of internationalisation is difficult to define, with many policy documents and academic articles on the subject simply taking its meaning for granted. Jane Knight, one of the most influential scholars of internationalisation, has defined the concept as 'the process of integrating an international, intercultural, or global dimension into the purpose, functions or delivery of post-secondary education' (Knight, 2015: 2-3; see also Knight, 2004: 9-10). This definition reflects the prevailing focus in the literature on internationalisation either as institutional diffusion, in terms of establishing branch campuses and study abroad programmes, or as student and staff mobility. ${ }^{5}$ However, like the bulk of scholarly work on internationalisation, it does not acknowledge the increasing global and cross-border nature of academic co-operation and knowledge production - a central aspect of university activity and the focus of this essay. I therefore consider internationalisation as an umbrella term for a set of policies that aim to enable a university situated within a particular domestic context to expand its research and educational activities overseas. Thus, the internationalisation of university activity occurs across three interconnected spheres: increased academic mobility; the establishment of branch campuses in host countries; and the establishment of international research partnerships.

Scholars at British universities are encouraged to intensify their activities in this third sphere: in the words of Universities UK, the representative body for British universities, 'international collaboration is increasingly synonymous with excellent research' (Adams, 2017). According to a 2011 report by the Royal Society, over $35 \%$ of articles published in international journals have been produced through international collaboration, an increase of $10 \%$ in 15 years (Royal Society, 2011: 12). ${ }^{6}$ This collaboration has a clear benefit for authors: articles increase their impact with each additional international co-author (Royal Society, 2011: 59). ${ }^{7}$ The report states that the primary reason for scholars to engage in international collaboration is to 'enhance the quality of their work, increase the effectiveness of their research, and overcome logistical obstacles by sharing costs, tasks and expertise' (Royal Society, 2011: 57). The view of international collaboration as inherently beneficial is also shared by the Higher Education Academy, which states in a recent consultancy document that international alliances can help maintain credibility, currency and provide sources of evidence to support achievement and progression in teaching and research' (HEA, 2015).

Driving the contemporary internationalisation of universities is the emergence of a global knowledge economy in which intellectual assets, such as technological advances, software innovations and human capital are seen as critical for the success of national economies. Consequently, universities, as centres of research, development and knowledge transfer have become an important focus of national policy-making (Hazelkorn, 2015). And in order for universities to become/remain competitive in the globalised academic market, where competition for resources, students and staff has transcended national boundaries, a process of convergence of university activities is taking place - in terms of courses offered, the structure of degree programmes, and what is considered excellent research - most obviously evidenced in the proliferation of international ranking systems based on a narrow set of criteria drawn from the model of the Euro-American university. These ranking systems have served to reify, consolidate and reproduce 'existing concentrations of wealth, technology and knowledge power', whose primary locations are in the West but in which East Asia is growing in influence (Marginson, 2009: 28). 
While not all aspects of the internationalisation agenda run counter to a decolonising project, the prerogative of encouraging faculty in the Global North to establish research partnerships with universities in the Global South tends to be based on a form of intellectual - or epistemic - colonialism. This is due to the hegemonic ensemble of global ranking systems, citation indexes and Englishlanguage scientific journals, which serves to force the universities of the world to pursue a narrow, largely empiricist-rationalist, mode of knowledge production. Western-based researchers are required by both their funders and their managers to seek out international research collaboration with those universities that score highly on these Western-centric yet globalised markers of scholarly excellence, which themselves are rooted in European Enlightenment values of empiricism, objectivity and secular rationality (Grosfoguel, 2007: 213). While I do not dispute the importance of cultivating the cross-cultural production of knowledge - indeed, the relationships that sustain this process can be some of the most intellectually stimulating and enriching of all - the epistemological challenges and ethical dilemmas involved in this process are consistently absent from mainstream debate, only to be found in the broader work of explicitly decolonial authors. These authors argue that the globalisation of the Western university model has marginalised and even eradicated non-Western ways of knowing, a process which, as Icaza and Vázquez have pointed out, 'belongs to the history of the Western project of civilization' (Icaza and Vázquez, 2018: 111; see also Vázquez, 2015: 95). They state that the knowledge production in the internationalised university is based on 'an epistemology that is at one and the same time pretending to be wide-ranging, or even claiming universal validity, while remaining oblivious to the epistemic diversity of the world' (Icaza and Vázquez, 2015: 112). Motta has termed this condition 'epistemological blindness' (Motta, 2013). According to Santos, such wilful epistemological blindness produces 'monocultures of knowledge', which consist of 'turning modern science and high culture into the sole criteria of truth and aesthetic quality, respectively' (Santos, 2014: 272). In short, the very institution tasked with the goal of understanding the world in all its diversity is blocking itself off from that diversity as economic imperatives drive the convergence of practices of knowledge production among individual universities. And the internationalisation agenda, with its league tables and impact factors, is accelerating this trend.

What is to be done? To recognise that knowledge production occurs differently in different cultural settings may, in some instances, lead not to the opening of epistemological space so desired by decolonial scholars, but instead to the very closure of this space. Indeed, hasty attempts to conduct research activities with academic partners in states whose universities are not premised on pluralism, independence and critique may jeopardise, rather than enhance, scholarly credibility and research quality since scholars are required to limit research agendas in order to bolster the hegemonic narratives and development strategies of non-liberal governments. However, given the economic logic sustaining the internationalisation agenda, a profitable international collaboration is frequently prioritised over a commitment to pluralism. The following section discusses this tension in relation to China, whose government is seeking to challenge and redefine the current norms of knowledge production favoured by Euro-American universities.

\section{China - A Rising 'Status Quo or Revisionist' Intellectual Power?}

In the International Relations (IR) literature on the rise of China, one of the most commonly asked questions is whether it is a 'status quo' or a 'revisionist' power. In other words, will China, as it increases its economic, military and soft power relative to that of Western states, seek to challenge the norms and values of the liberal international order established by the West in the aftermath of the Second World War, or will it seek to co-ordinate its rise within this order (Johnston, 2003; Kastner and Saunders, 2012; Chin and Thakur, 2010)? The same question might be asked of its approach to the global system of higher education. As Chinese universities receive ever greater levels of funding by the Chinese government and concomitantly leapfrog up international league tables, will China seek 
to reshape the epistemological norms underpinning global higher education? Recent confrontations between China and Euro-American universities suggest that this may be the case. To paraphrase Elizabeth Economy, China's illiberal higher education system is seeking leadership in a liberal global system (see Economy, 2018: 17).

The rise of Chinese academia is certainly impressive: following large injections of funding by central government from the 1990s onwards, Chinese universities have rapidly ascended the global league tables, with its prestigious C9 League exhibiting a yearly growth rate of $12.8 \%$ and even overtaking Canada's elite U15 group of universities in 2014 (Allen, 2017: 405). ${ }^{8}$ Chinese universities now produce the second highest volume of research output in the world and could overtake the US in research impact as soon as the mid-2020s, according to some estimates (Royal Society, 2011: 16; Baker, 2018). Accompanying their rise are energetic attempts by UK actors to increase collaborations with Chinese universities. In the four years between 1996 and 2000, the number of co-authored papers between scholars in UK and Chinese institutions increased by $63 \%$, a trend which is likely only to have intensified in the ensuing years (HM Government, 2013: 50). The UK government has proclaimed the importance of embracing this shift in the league tables, writing in a 2013 report that 'future success will depend on the UK's ability not only to continue collaborating with excellent research and innovation in traditional partner countries, but also to position ourselves to make the most of the opportunities emerging in this new global landscape' (HM Government, 2013: 49). Later that year, then Universities Minister, David Willetts, published a host of policies aimed to increase integration between UK and Chinese universities and, by 2018, all Russell Group institutions reported significant links with Chinese counterparts (Gov.UK, 2013; Russell Group, 2018).

However, China's internationalising trend in higher education has been accompanied by domestic attempts to curb the influence of educational norms and values associated with the West. In November 2013, the Chinese Communist Party (CCP) published a controversial communique that has come to be known as Document 9, which critiqued liberal modes of thought, listing seven topics that should be forbidden from public discussion in China. These include the idea of universal values (which suggests that the Western system of values 'defies time and space, transcends nation and class, and applies to all humanity'), Western ideas of journalism (which challenge the idea that journalistic output should be subject to Party control) and the notion of individual rights inherent within the concept of civil society. ${ }^{9}$ Clearly, universities are one of the key sites through which such 'false ideological trends' may be spread (ChinaFile, 2013). This view was reinforced two years later in 2015, when the Chinese Minister of Education caused uproar by stating that Western values were 'not suitable for class' (Mai, 2016). It appears that the internationalisation agenda's imperative of creating transborder research partnerships directly contradicts trends in the domestic governance of higher education in China.

Indeed, the growing collaboration between Chinese and Western universities is increasingly marred by confrontation over matters related to the politics of knowledge production. For instance, Chinese students are periodically accused of espionage, with US President Donald Trump reportedly stating of China that 'almost every student that comes over to this country is a spy' (Redden, 2018). The institutional locus for this activity is considered by some to be Confucius Institutes, China's centres for language cultural education which operate on university campuses around the world. Various Western commentators have accused them of espionage, monitoring Chinese students studying abroad, and acting as tools for the advancement of Beijing's global political agenda, and have variously described them as a 'Trojan horse with Chinese characteristics' (Hartig, 2015) and 'academic malware' (Sahlins, 2015). Human Rights Watch's recently published 12-point 'Code of Conduct' for universities that engage with China and wish to 'resist Chinese government efforts to undermine academic freedom abroad' even suggests that universities should decline to host Confucius Institutes, calling them 'fundamentally incompatible with a robust commitment to academic freedom' (HRW, 2019). 
While of course much collaboration between Chinese and Western academic institutions and individuals continues successfully and without incident, several high-profile projects have recently been cancelled over concerns about CCP influence in the production of knowledge. In January 2018, the University of Groeningen in the Netherlands cancelled plans to launch a campus in China's Shandong Province after it emerged that the campus' most senior figure would be a CCP official (SCMP, 2018) and, in October 2018, Cornell University in the US announced that it would be suspending two academic exchanges and a research programme with Renmin University of China due to concerns about academic freedom (Yang, 2018). Western scholars working on topics considered politically sensitive by the Chinese government have sometimes been denied visas leading to what has been described as an 'epidemic of self-censorship' among US-based scholars working on China, in which it is increasingly common to avoid publishing on subjects seen as politically sensitive in case future visa applications are rejected (Fish, 2018; see also Chestnut Greitens and Truex, 2019).

Perhaps the most controversial case of censorship was the decision in August 2017 by Cambridge University Press, which publishes the respected China Studies journal, The China Quarterly, to remove over three hundred articles from the journal's online platform in China at the request of the Chinese government. During the ensuing outcry and the articles' ultimate reinstatement, it emerged that other global journals had complied with similar requests and that numerous non-Chinese publishing houses enacted self-censorship in order to access the Chinese education market (Bothwell, 2017; SCMP, 2017). In an editorial published by an influential Chinese English-language newspaper, The Global Times, the censorship was portrayed as a matter of domestic cyber security. The authors wrote,

'China has blocked some information on foreign websites that it deems harmful to Chinese society. This is for the sake of China's security and is within the scope of China's sovereignty. China is also trying to strike a balance between opening itself up and preventing harmful external information from penetrating into Chinese society, to realize steady and sustainable progress' (Global Times, 2017).

In other words, for China, national security better serves the common good than freedom of information. The individual freedom of scholars to pursue independent (and potentially critical) research agendas is a specifically Western, not a universal, value and hence does not apply to China. This issue is particularly salient in the Humanities and Social Sciences, where critical perspectives on governance, including Chinese governance, are frequently articulated. Western scholarly organisations seeking to increase their activities in China must therefore make a choice: comply with Chinese regulations and limit access to information that the Chinese government deems harmful, or lose access to the lucrative Chinese market. This incident all too clearly demonstrates how anticipated economic benefits of internationalisation may directly contradict and undermine the epistemological foundations of the Western university, based as it is on the independence of scholars to articulate potentially critical views (see Hertzog, 2017). It indicates that the unfettered market-driven internationalisation of knowledge production can only lead to a global reduction in academic freedom.

Broadly understood as the 'freedom to teach and conduct research without fear or concern of retribution' (Tierney and Lanford, 2014: 4), the question of academic freedom has risen to the forefront of debates about engagement between Chinese and Western universities in recent years. Some consider academic freedom a universal and absolute concept that should be defended across time and space (Tierney and Lanford, 2014: 20; Altbach, 2015). ${ }^{10}$ Others argue that it is a Western value that is particular to the Western university system and cannot be exported to different national contexts (Hayhoe, 2011: 17; Marginson, 2014: 25). So great are the economic and political implications of this debate that iterations have even reached the top levels of British government. In spring 2019, Chair of the Foreign Affairs Committee, Tom Tugendhat MP, wrote to the Chair of Universities UK, 
Janice Beer, stating that, 'concerns have been raised about the possibility that foreign countries might seek to exploit the openness of our world-leading universities to exert improper influence for political ends' and asking whether UUK has any relevant information in this regard. In her reply, Beer stated that given the global nature of academia and the diversity of political regimes with which UK universities co-operate 'universities must sensitively balance the need to uphold academic freedom with the importance of international academic collaboration'. ${ }^{11}$

On one hand, there are obvious traces of colonial thinking in attempts to universalise this historically and culturally specific value: the idea that Western academia is superior due to its commitment to academic freedom and that Chinese scholarship is impoverished due it its subjection to government control feeds into a deeply uncomfortable narrative of Western supremacism and Eastern 'backwardness'. On the other hand, the idea that the Chinese government should act as a type of global epistemic policeman is virtually impossible to reconcile with the cultural understandings of good research prevalent in the West. Ironically, however, this dichotomy is ultimately false at the level of practice: for in imposing academic freedom on knowledge creators located outside of its particular cultural sphere, one ends up denying the very epistemological pluralism upon which academic freedom is founded.

One potential way out of this impasse is to situate epistemological practices in their historical, social and cultural contexts, since understanding the reasons behind China's illiberal approach to knowledge production may help to locate a bridge between these two apparently incommensurable standpoints. In the following section, I seek to understand Chinese practices of knowledge production on their own terms by considering how China's Confucian heritage, political environment and rapid economic development are impacting its domestic knowledge economy.

\section{Situating the Production of Chinese Social Science}

A small but growing body of work has begun to examine the social context of knowledge production in spaces beyond the European/Western ontological sphere (Amsler, 2007; Kaczmarska, 2019). This work takes seriously the Habermasian insight that the production of knowledge is shaped by and hence inseparable from human interests - or, to be more specific, state interests - and questions the epistemological separation of science and politics presumed in some of the Eurocentric literature (see Jahn 2017). A contextual approach suggests that our social and political environments shape what we can know (see Harding, 2007), and hence, in order to understand other epistemological standpoints, we must also understand the contexts in which they were produced. In recognition of the situated nature of knowledge production, this section seeks to understand the social and historical factors that shape the epistemological foundations of social science in China. To do so, I briefly consider three perspectives: first, a cultural perspective, which examines China's Confucian heritage; second, a political perspective, which foregrounds the increasingly authoritarian control of China's public sphere under Xi Jinping; and third, an economic perspective which focusses on China's remarkably swift transformation away from its previous status of a 'developing country'. ${ }^{12}$

The question of the extent to which culture influences knowledge has been the subject of much debate (Oyserman and Lee, 2008)..$^{13}$ The influential social psychologist Richard Nisbett, in his widely cited study of difference in Western and Eastern modes of thought has concluded that 'people hold the beliefs they do because of the way they think and they think the way they do because of the nature of the societies they live in' (Nisbett, 2003: 201). Summarising some of the differences, he writes,

'The collective or interdependent nature of Asian society is consistent with Asians' broad, contextual view of the world and their belief that events are highly complex and determined by many factors. The individualistic or independent nature of Western 
society seems consistent with the Western focus on particular objects in isolation from their context and with Westerners' belief that they can know the rules governing objects and therefore can control the objects' behaviour' (Nisbett, 2003: xvii).

Of course, this ethnocentric and culturally relativistic view has been roundly challenged: Nisbett's binary logic eschews both the internal diversity within 'Asian' and 'Western' epistemic communities and the similarities that exist between them, which are many (Chan and Yan, 2007; Ryan and Louie, 2007; Ryan, 2010). Nevertheless, Confucianism as one of the primary organising principles of East Asian culture deserves consideration for its influence on the development of Chinese scholarship.

The Confucian approach to knowledge is deeply bound up with ethics, morality and virtue: one becomes a wise person by adhering to the ethical values of humbleness, kindness, respectfulness and justice. However, the practice of Chinese Confucianism can be seen to comprise two strands. First, state Confucianism was embodied in a variety of institutions, including the keju state examination process, which prepared individuals for government office and presumed a close link between scholarly learning and government activity. The second strand as practiced by everyday people, while adhering to the general principle of harmony, was nevertheless open to entertaining conflicting viewpoints. ${ }^{14}$ Hence, although Confucianism is typically seen to value the preservation of social harmony and respect for authority (Hung, 2016; Bell, 2008; see also Confucius, 2013), there are numerous examples of Confucian scholars who stood up for what they believed to be right against Ming Dynasty rulers, and sometimes paid for it with their lives. ${ }^{15} \mathrm{Wm}$ De Bary has noted an individualist trend in neo-Confucian thought, that highlighted taking personal responsibility (ziren), finding contentment in oneself (zide), and the cultivation of oneself as a sage (De Bary, 2013). Later, during the Republican Period, the Chancellor of Peking University, Cai Yuanpei, when instituting various structural measures to ensure the university's independence from the government, argued, 'I am open to all schools of thought; according to the general standards of the universities of all nations and the principle of freedom of thought, I believe we should be inclusive of diverse viewpoints' (Hayhoe et al., 2011, 97). Therefore, to claim that Confucianism's alleged valorisation of hierarchy and conformity is the defining factor in China's approach to academic freedom is incorrect.

Turning now to the impact of recent political developments on the social sciences in China, as suggested in the preceding section, the domestic political environment in China has become much more restrictive since Xi Jinping assumed presidency in 2012, with staff and students subjected to an intensification of Marxist training and ideological monitoring (Gan, 2017). According to Zhao Suisong, ' $X i$ is trying to revive communism as an official ideology because communism's demise amid the reforms that followed Mao's death not only eroded the CCP's legitimacy and weakened its mass support, but also led some Chinese intellectuals to turn toward Western liberalism as an alternative' (Zhao 2016: 83). This has had profound consequences for the Chinese university, leading the CCP to play a greater role in the production of social science knowledge.

Chinese universities are, however, no strangers to intense government involvement in knowledge production. During the Maoist era, penalties for pursuing research agendas that deviated from the Party line involved periods of hard labour or even, in some cases, a death sentence. In 1952, the discipline of Sociology was banned as a 'bourgeois social science' and, by 1953 , fewer than $15 \%$ of students were studying social sciences (Kang, 2004: 141). During the decade of the Cultural Revolution (1966-1976), university education suffered greatly: students ceased to enrol in programmes and academics were seen as objects of hate. These developments have precipitated a enduring culture of self-censorship among Chinese academics (He, 2002). Despite the modest liberalisation of the reform era under Deng Xiaoping, the Chinese university system remains governed both by the university administration and by the CCP, with the former subordinated to the latter (Frenkiel, 2015: 17). Public adherence to CCP ideology is therefore required for both staff and students: each university and 
college also hosts a Party committee, whose aim is to oversee Party activities on campus, and students take compulsory ideology classes in Mao Zedong and Xi Jinping Thought. This close relationship between the government and the university has led Zha and Hayhoe to describe the Chinese university as 'the government's educational and research arm for economic and social development' (Zha and Hayhoe, 2014: 45).

At the same time, to characterise Chinese Humanities and Social Sciences as uniform mouthpieces of the CCP would also be a grave error, since wide diversity of scholarly opinion exists on the key issues facing China (see Frenkiel, 2015). Many professors at China's top universities have obtained their PhDs from US or British universities, with the government tolerating critical voices - as long as they remain within the academy and removed from broader societal influence. Generous funding opportunities are available from the Chinese government for PhD study abroad, demonstrating that Chinese academia has in many ways embraced the Western educational norms associated with the internationalisation agenda. Hence, to place the construction of knowledge within China solely in the context of repressive tendencies under Xi Jinping is also short-sighted.

The third major influence shaping the production of social science knowledge in China is the country's rapid economic growth - without historical parallel. The Chinese government has sought to transform Chinese academia into a world class university system in a matter of decades. Behind this drive is a desire to demonstrate China's new status as an advanced nation: at the Meeting of National Philosophy and Social Sciences Academics in May 2016, Xi stated 'the developmental level of a country is determined by both its advances in natural sciences and philosophy/ social sciences' (Gao and Zheng 2018: 5). ${ }^{16}$ Yet the speed of this transformation has contributed to a number of contradictions, some of which have been discussed above: the criticism of 'Western educational values', while valorising those with Western PhDs; the requirement for scholars to publish in high ranking international journals, while adhering to the doctrine of Marxism-Leninism; the on-going establishment of international academic collaborations while disavowing the epistemological norms that underline the research produced by collaborating institutions.

These contradictions remind one that Chinese academia is still very young compared to universities in Europe. China's first modern universities - such as Peking, Nanjing and Tianjin Universities - were founded only at the end of the nineteenth century, as 'self-strengthening institutes' following the colonial domination experienced during and after the First and Second Opium Wars. The Chinese Academy of Social Sciences was only established in 1977 and universities did not assume a research function until the early 1980s, having been limited to teaching under the Soviet model after the revolution (Frenkiel, 2014). Hence, we may expect a lag in academic practices and approaches to knowledge production in some of China's universities, given the speed with which its university has transformed. In light of this recent history, the fact that a Chinese university - Tsinghua - has appeared in the Times Higher Education's World University Rankings 2019 in the global top fifty universities in which to study for a social science degree (with Zhejiang University coming in between 101 and 125) is nothing short of miraculous (THE, 2018).

The logics that influence and shape Chinese epistemological approach are constantly interacting and reinforcing one another. Some of these factors may change over time - for example, China's political environment may liberalise or become more tightly restricted (see Shambaugh, 2016) - while others remain enduring cultural influences. Further, as Chinese academic continues to mature, we may see an ironing out of some of the logical inconsistencies highlighted above. How might a UK-based scholar navigate these differences in the practical forging of transnational research partnerships as required by the internationalisation agenda? The following, final section draws on decolonial literature in the field of epistemology to suggest that opening space to accommodate a variety of approaches to knowledge production can only result in the ultimate closure of this space if anti-liberal approaches 
are included in this space, such as that practiced in the social science departments at many Chinese universities.

\section{Decolonising the Internationalisation Agenda in an Illiberal World?}

As outlined in the first section, the current programme of internationalisation advanced by the global higher education system endorses epistemic colonialism. Is this type of colonialism permissible given the advance of anti-liberal academic practices undertaken by states seeking to control social and political narratives? Colonialism is an illiberal practice in itself; endorsing colonialism to fight illiberalism at the very least amounts to circular logic, if not reprehensible ethical practice. There are two main ways in which the epistemological hegemony of European Enlightenment norms can be challenged: a 'weak' liberal challenge and a 'strong' decolonial challenge. While the decolonial challenge resolves the question of how to 'provincialise' hegemonic European epistemologies, the question of how - or indeed whether - to challenge the rising epistemic anti-liberalism that is filling the space vacated by provincialized European epistemologies remains unanswered.

The liberal challenge advances a multiculturalist solution by suggesting that space within existing frameworks be opened for minority groups so that they may integrate on an equal footing with the dominant group (see Kymlicka, 1995). However, Maldonado-Torres et al (2018: 66) have argued that any attempt to challenge the supremacy of European values in the university 'cannot be satisfied with simply adding new areas to an existing arrangement of power/knowledge, leaving the Eurocentric norms that define the field as a whole in place, or reproducing such norms themselves'. For them, the liberal project of simply diversifying the canon forces non-Western forms of knowledge to conform to the standards set by the modern, colonial university. ${ }^{17}$ Similarly, Santos argues that the progressive Western-centric answer to the question of how to account for and recognise a diversity of ways of knowing, which claims that 'such diversity is only to be recognized to the extent that it does not contradict universal human rights' (Santos, 2014: 41; see also Nisbett, 2003: 198-199) is insufficient to decolonise epistemologies because it 'reduces the understanding of the world to a Western understanding of the world' (Santos, 2014: 42). In other words, liberalism's universalistic epistemological foundations suggests that all phenomena may ultimately be categorised according to the same terms and acted upon in similar ways - an assumption upon which the discussion of the Chinese approach to knowledge production above casts doubt.

The campaign group, Rhodes Must Fall Oxford (RMFO), which has sought to challenge the supremacy of Eurocentrism and whiteness in academia, states that a key means to decolonise the university is to 'remedy the highly selective narrative of traditional academia - which frames the West as sole producers of universal knowledge - by integrating subjugated and local epistemologies' (RMFO Campaign, quoted in Gebrial, 2018: 23). Such an approach involves a recognition of the colonial underpinnings of the Enlightenment project and a recognition of the erasure of the intellectual contributions from Islamic, Persian, Chinese and South Asian philosophical and scientific writings from European and 'Western' forms of rationality (Gebrial, 2018: 27). A properly decolonial approach to epistemology would therefore not simply embrace epistemological pluralism, but instead conduct a thorough and on-going genealogy of the fusion and cross-pollination of Western and non-Western ways of knowing on the one hand and the subjection and erasure of the latter on the other. Santos counsels scholars and activists in the Global South not to disregard Western ways of knowing in their entirety, but to maintain an awareness that the 'diversity of world experience is inexhaustible and therefore cannot be accounted for by any single general theory' (Santos, 2014: 76), an observation that chimes with Levine and McCourt's call for epistemological pluralism discussed in the introduction. Santos advances the concept of 'ecology of knowledges', which 'assumes that all relational practices involving human beings and human beings and nature entail more than one kind of knowledge' (Santos, 2014: 297) In a similar vein, Mignolo states that, 
'belonging to a world that has been classified as traditional and irrational means that any attempt to mobilize from that position will have to assume that the conditions of being irrational and traditional have been allocated from the epistemic privilege of a mythical space/time called "modernity." However, since the epistemic privilege goes hand in hand with its hegemony, its displacement implies subsuming the first set of terms in the paradigm into the second by making of it a locus of enunciation as legitimate as the first' (Mignolo, 2002: 941-942).

In the case of China, this would mean, presumably, that in order to decolonise transnational research partnerships, the Chinese Communist Party should be seen as a legitimate locus of enunciation. The fact that the CCP may subsequently seek to establish a hegemonic discourse and close down alternative narratives is not considered. Likewise, Santos' proposal to maintain a commitment to a plurality of knowledges when creating research partnerships is only possible if both partners adhere to it. If one side rejects such pluralism, the whole 'ecology' collapses. This illustrates that, while the decolonial approach to epistemology has made vital steps towards dislodging the centrality of Eurocentric forms of knowledge, it also suffers from a central weakness because it does not distinguish between the emancipatory potential of the various approaches to knowledge production advanced by marginalised groups and appears to consider decolonisation as an end it itself. It contains no insights into how to maintain a decolonised epistemological space.

What does this mean for the internationalisation agenda? Ironically, whether one chooses to 'force' adherence to academic freedom through practices of epistemic colonialism or allow non-liberal governments to shape and direct research agendas, the result is less epistemic pluralism, not more. Ceding space only to those approaches to knowledge production that foster critique and pluralism suggests the problematic approach that decolonisation is allowed, but only if alternative approaches produce knowledge 'like we do'. The fact is that liberal and anti-liberal approaches to epistemology are simply incommensurable. As the internationalisation agenda brings universities ever closer together, therefore, liberal internationalist approaches to scholarly practices appear likely to recede.

\section{Conclusion}

The creation of international research partnerships presumes that the co-production of knowledge is possible across cultures, borders and epistemological traditions. Furthermore, the on-going and deepening entanglements between universities around the world has led to the view that 'it is both natural and desirable for knowledge to accumulate into one international pool of ideas and methods, freely accessible to all' (Easton, 1991: 22). Yet, as I have highlighted in this essay, while such aspirations are highly commendable in theory, in practice they are fraught with epistemological and ethical problems. These problems centre around the fact that social science knowledge is produced differently and serves different social purposes in different cultural contexts. In the UK, such knowledge is generally produced through critical engagement with existing sources, a diversity of perhaps contradicting truth claims may be articulated simultaneously by a variety of scholars and groups, and scholars are not afraid to engage in research that potentially contradicts or undermines government policy. In China, knowledge production often functions quite differently: the goal of social research is to promote social harmony and advance the government's vision of social and economic development. This is achieved through a disavowal of potentially destabilising research agendas and an on-going close collaboration between universities and the Party. Although these epistemologies appear incommensurable, the process of internationalisation of universities around the world is bringing scholars socialised in the two traditions ever closer together and this trend is only likely to intensify. 
I have argued above, following scholars of decolonial epistemology, that the Western epistemological tradition promoted and sustained by the complex of international rankings systems, scholarly journals and transnational funding bodies marginalises subaltern ways of knowing. Yet the two critiques of this system - the liberal and decolonial approaches - are unable to offer adequate means with which to address the narrowing space for pluralism in global knowledge production. The universalism underpinning liberal 'diversity' approach neither provides a sufficient critique of how Enlightenment epistemological values came to be, nor suggests an effective way of bridging the epistemic divide between academic freedom and government control, while the decolonial approach appears to suggest that illiberal entities, such as the CCP, are legitimate epistemic actors. We are faced with an unpleasant choice of allowing Western epistemological hegemony to go unchallenged or to allow governments to limit research agendas.

Is the rise of epistemological illiberalism inevitable, then? I do not seek to provide an answer to this probably unanswerable question. Instead, I have attempted to foreground this tension within the internationalisation agenda with the aim of encouraging broader reflection on how we can foster 'a genuine attempt to learn from an unfamiliar "other"' (Ryan and Louie, 2007: 405) while being mindful of the fragility of the values upon which the Western university is based. Here, much depends on the approach of individual scholars. While recognising multiple epistemologies can open a back door to an erosion of academic freedom, rather than disengaging with those working in illiberal environments or mindlessly pursuing the economic benefits of internationalisation at the expense of commitments to academic freedom, researchers need to adopt a critical and reflexive orientation to their own culture in order to recognise how the normative assumptions that underpin research practices may come into conflict with scholars working within different epistemological traditions. Importantly, epistemologies are not fixed, social contexts are constantly evolving and both liberal and illiberal forces may rise or recede in any political context, including our own. I end this essay by returning to Isaiah Berlin, let us as scholars aspire to approach epistemology as foxes rather than as hedgehogs, even when faced with an illiberal other.

\footnotetext{
${ }^{1}$ Many scholars have highlighted the economic drivers behind the internationalisation agenda. See Chan and Fisher, 2009: 206; Jöns and Hoyler, 2013; Altbach and Knight, 2007: 291; Koch, 2014: 46.

${ }^{2}$ In the remainder of the article I use the terms 'Euro-American' and 'Western' interchangeably when referring to epistemology and the university. While I recognise that the concept 'Western' is both vague and (geo)politically charged, universities in Europe and the US developed along similar trajectories (due to the British colonisation of North America) and are based on similar approaches to knowledge production and academic freedom. See Schrecker, 2010: 11-13.

3 Enrique Dussel has shown how this objectivity and universalism, begun with René Descartes, is in fact founded precisely on a prior colonial and imperial epistemology. See Grosfoguel, 2007.

${ }^{4}$ Pierre Bourdieu argued that disciplinary knowledge in Western academia may represent itself as neutral and objective, but in fact involves symbolic violence and power over what forms of knowledge count as 'worthy'. See Bourdieu, 1984.

${ }^{5}$ For a review of this literature see Koch, 2014.

${ }^{6}$ The report also notes that the vast majority of these publications are in the natural sciences, with publications in the humanities and social sciences accounting for $8.9 \%$ of the total publication output.

${ }^{7}$ This impact levels off at ten authors.

${ }^{8}$ The C9 League refers to the group of 9 elite Chinese universities selected for development and international promotion by the government.

${ }^{9}$ For a translation of the Document see ChinaFile, 2013.

${ }^{10}$ Michael Polanyi argued, for instance, that it is only through academic freedom that knowledge can be advanced. See Polanyi, 1975.

${ }^{11}$ This exchange has been placed in the public domain and is available at:

https://www.gov.uk/government/news/free-speech-to-be-protected-at-university
} 
12 However, China has sought to retain its status as 'developing country in the World Trade Organization, which entitles it to preferential trade rules. See Lee, 2019.

${ }^{13}$ In Science and Technology Studies, the idea that scientific knowledge and society are co-constitutive and are formed in a process called co-production is central to the discipline. See Jasanoff, 2004.

${ }^{14}$ I am grateful to one of the reviewers for pointing this out.

${ }^{15} \mathrm{Wm}$ Theodore De Bary cites the examples of Fang Xiaoru (1357-1402) and Hai Rui (1513-1587), who were ultimately executed for failing to cease petitioning the Emperor (De Bary, 2013: 134-135).

${ }^{16}$ In the same speech, he stipulated that philosophy and the social sciences should be guided by Marxism and Leninism.

${ }^{17}$ For a discussion of how this debate has played out in the IR literature, see Owen et al, 2018.

\section{References}

Adams, Jonathan (2017) 'International Research Collaboration after the UK Leaves the European Union', A report from Digital Science Consultancy for Universities UK. Available at: https://www.universitiesuk.ac.uk/policy-and-analysis/reports/Documents/2017/internationalcollaboration-uk-post-exit.pdf

Allen, Ryan M. (2017) 'A Comparison of China's "Ivy League" to Other Peer Groupings Through Global University Rankings', Journal of Studies in International Education 21 (5): 395-411.

Altbach, Philip G. (2015) 'The Costs and Benefits of World-Class Universities', International Higher Education. Available at: http://ejournals.bc.edu/ojs/index.php/ihe/article/viewFile/7381/6578.

Altbach, Philip G. and Jane Knight (2007) 'The Internationalization of Higher Education: Motivations and Realities' Journal of Studies in International Education 11 (3/4): 290-305.

Amsler, Sarah (2007) The Politics of Knowledge in Central Asia: Social Science between Marx and the Market, (Abingdon: Routledge).

Baker, Simon (2018) 'China Could Overtake US on Research Impact by mid-2020s', Times Higher Education, 12 July 2018. Available at: https://www.timeshighereducation.com/news/china-couldovertake-us-research-impact-mid-2020s

Barnes, Barry and David Bloor (1982) 'Relativism, Rationalism and the Sociology of Knowledge' in Martin Hollis and Steven Lukes (eds.) Rationality and Relativism (London: Blackwell).

Bell, Daniel A. (2008) China's New Confucianism: Politics and Everyday Life in a Changing Society (Princeton: Princeton University Press).

Berlin, Isaiah (2013 [1953]) The Hedgehog and the Fox (Princeton, NJ: Princeton University Press).

Bothwell, Ellie (2017) 'Chinese power "may lead to global academic censorship crisis"', Times Higher Education, 7 December 2017. Available at: https://www.timeshighereducation.com/news/chinesepower-may-lead-global-academic-censorship-crisis

Bourdieu, Pierre (1984) Homo Academicus, trans. Peter Collier (Stanford, CA: Stanford University Press).

Chakrabarty, Dipesh (2000) Provincializing Europe: Postcolonial Thought and Historical Difference (Princeton: Princeton University Press). 
Chan, Adrienne S. and Donald Fisher (2009) The Exchange University: Corporatization of Academic Culture (Vancouver, BC: UBC Press).

Chan, Ho Mun and Hektor K.T. Yan (2007) 'Is There a Geography of Thought for East-West Differences? Why or why not?' Educational Philosophy and Theory 39 (4): 404-417.

Chen, Shuangye and Bruce Macfarlane (2015) 'Academic Integrity in China' in Tracey Bretag (ed.) Handbook of Academic Integrity (Singapore: Springer Verlag).

Chestnut Greitens, Sheena and Rory Truex (2019) 'Repressive Experiences among China Scholars: New Evidence from Survey Data', The China Quarterly, First View.

Chin, Gregory and Rimesh Thakur (2010) 'Will China Change the Rules of Global Order?', The Washington Quarterly 33 (4): 119-138.

ChinaFile (2013) 'Document 9: A ChinaFile Translation', 8 November 2013. Available at: http://www.chinafile.com/document-9-chinafile-translation.

Confucius (2013) Confucian Analects, The Great Learning and the Doctrine of the Mean, James Legge (trans.) (Mineola, NY: Dover Press, Inc.).

De Bary, Wm Theodore (2013) The Great Civilized Conversation: Education for a World Community (New York: Columbia University Press).

Dennis, Carol (2018) 'Decolonising Education: A Pedagogic Intervention' in Gurminda K. Bhambra, Dalia Gebrial and Kerem Nişancığlu (eds.) Decolonising the University (London: Pluto Press).

Easton, David (1991) 'The Division, Integration and Transfer of Knowledge', Bulletin of the American Academy of Arts and Sciences 44 (4) 22.

Economy, Elizabeth (2018) The Third Revolution : Xi Jinping and the New Chinese State (Oxford: Oxford University Press).

Fish, Isaac Stone (2018) 'The Other Political Correctness: Why are America's elite universities censoring themselves on China?', New Republic, 4 September 2018. Available at: https://newrepublic.com/article/150476/american-elite-universities-selfcensorship-china

Frenkiel, Emilie (2015) Conditional Democracy: The Contemporary Debate on Political Reform in Chinese Universities (Colchester, UK: ECPR Press).

Gao, Xuesong (Andy) and Yongyan Zheng (2018): 'Heavy mountains' for Chinese Humanities and Social Science Academics in the Quest for World-Class Universities', Compare: A Journal of Comparative and International Education. Online first.

Gebrial, Dalia (2018) 'Rhodes Must Fall: Oxford and Movements for Change' in Gurminda K. Bhambra, Dalia Gebrial and Kerem Nişancığlu (eds.) Decolonising the University (London: Pluto Press). 
Gan, Nectar (2017) 'Chinese universities tighten ideological control of teaching staff', South China Morning Post, 28 August 2017. Available at: https://www.scmp.com/news/china/policiespolitics/article/2108597/china-universities-tighten-ideological-control-teaching.

Global Times (2017) 'China Quarterly Debate a Matter of Principle', The Global Times, 20 August 2017. Available at: http://www.globaltimes.cn/content/1062304.shtml.

Gov.UK (2013) 'Press Release: New Links Between UK and China Universities' $5^{\text {th }}$ December 2013. Available at: https://www.gov.uk/government/news/new-links-between-uk-and-china-universities.

Grosfoguel, Ramón (2007) 'The Epistemic Decolonial Turn', Cultural Studies 21 (2-3): 211-233.

Harding, Sandra (2007) 'Rethinking Standpoint Epistemology: What is "Strong Objectivity"?' in K. Brad Way (ed.) Knowledge and Inquiry: Readings in Epistemology, (Ontario: Broadview Press). 352384.

Hartig, Falk (2015) 'Communicating China to the World: Confucius Institutes and China's Strategic Narratives', Politics 35 (3-4): 245-258.

Hayhoe, Ruth (2011) 'Introduction and Acknowledgements' in Ruth Hayhoe, Jun Li, Jing Lin and Qiang Zha (eds.) Portraits of $21^{\text {st }}$ Century Chinese Universities: In the Move to Mass Higher Education (University of Hong Kong: Springer).

Hayhoe, Ruth, Qiang Zha and Yan Fengqiao (2011) 'Peking University - Icon of Cultural Leadership' in Ruth Hayhoe, Jun Li, Jing Lin and Qiang Zha (eds.) Portraits of 21st Century Chinese Universities: In the Move to Mass Higher Education (University of Hong Kong: Springer).

Hazelkorn, Ellen (2015) Rankings and the Reshaping of Higher Education: the Battle for World Class Excellence, $2^{\text {nd }}$ Edition, (London: Palgrave MacMillan).

He Qinglian (2002) 'Academic Freedom in China', Academe 88 (3): 26-28.

Hertzog, Matthew (2017) Protections of Tenure and Academic Freedom in the United States: Evolution and Interpretation (Cham, Switzerland: Palgrave MacMillan).

Higher Education Academy (2015) frameWORKS 05, Internationalising Higher Education. Available at: https://www.heacademy.ac.uk/system/files/resources/InternationalisingHEframeworkFinal.pdf

HM Government (2013) 'International Education - Global Growth and Prosperity: An Accompanying Analytical Narrative'. Available at: http://dera.ioe.ac.uk/18071/14/bis-13-1082-internationaleducation-global-growth-and-prosperity-analytical-narrative Redacted.pdf

HRW (2019) 'China: Government Threats to Academic Freedom Abroad: New 12-Point Code of Conduct to Help Educational Institutions Respond', Human Rights Watch, 21 March 2019. Available at: https://www.hrw.org/news/2019/03/21/china-government-threats-academic-freedom-abroad.

Hung, Ruyu (2016) 'A Critique of Confucian Learning: On Learners and Knowledge', Educational Philosophy and Theory 48 (1): 85-96 
Icaza, Rosalba and Rolando Vázquez (2018) 'Diversity or Decolonisation? Researching Diversity at the University of Amsterdam' in Gurminda K. Bhambra, Dalia Gebrial and Kerem Nişancığlu (eds.) Decolonising the University (London: Pluto Press).

Jahn, Beate (2017) 'Theorising the Political Relevance of International Relations Theory', International Studies Quarterly, 61 (1): 64-77.

Jasanoff, Sheila (2004) States of Knowledge: The Co-Production of Science and the Social Order (Abingdon: Routledge).

Jöns, Heike and Michael Hoyler (2013) 'Global Geographies of Higher Education: The Perspective of World University Rankings', Geoforum 46: 45-59.

Johnston, Alastair lain (2003) 'Is China a Status Quo Power?’ International Security 27 (4): 5-56.

Kastner, Scott L. and Phillip C. Saunders (2012) 'Is China a Status Quo or Revisionist State? Leadership Travel as an Empirical Indicator of Foreign Policy Priorities', International Studies Quarterly 56 (1): 163-177.

Kaczmarska, Katarzyna (2019) BOOK TITLE TO BE CONFIRMED (London: Routledge).

Kang, Ouyang (2004) 'Higher Education Reform in China Today', Policy Futures in Education 2 (1): 141-149.

Knight, Jane (2015) 'Updating the Definition of Internationalization', International Higher Education 33: 2-3.

Knight, Jane (2004) 'Internationalization Remodeled: Definition, Approaches, and Rationales', Journal of Studies in International Education 8 (1): 5-31.

Koch, Nataile (2014) 'The shifting geopolitics of higher education: Inter/nationalizing elite universities in Kazakhstan, Saudi Arabia, and beyond', Geoforum 56: 46-54.

Kymlicka, Will (1995) Multicultural Citizenship: A Liberal Theory of Minority Rights (Oxford: Oxford University Press).

Lee, Amanda (2019) 'China refuses to give up 'developing country' status at WTO despite US demands', South China Morning Post, 6 April 2019. Available at:

https://www.scmp.com/economy/china-economy/article/3004873/china-refuses-give-developingcountry-status-wto-despite-us.

Levine, Daniel and David McCourt (2018) 'Why Does Pluralism Matter When We Study Politics? A View from Contemporary International Relations', Perspectives on Politics 16 (1): 92-109.

Mai, Jun (2016) 'Xi calls for more thought control on China's campuses', South China Morning Post, 10 December 2016. Available at: https://www.scmp.com/news/china/policiespolitics/article/2053362/xi-calls-more-thought-control-chinas-campuses

Maldonado-Torres, Nelson, Rafael Vizcaíno, Jasmine Wallace and Jeong Eun Annabel We (2018) 'Decolonising Philosophy' in Gurminda K. Bhambra, Dalia Gebrial and Kerem Nişancığlu (eds.) Decolonising the University (London: Pluto Press). 
Marginson, Simon (2014) 'Academic Freedom: A Global Comparative Approach', Frontiers of Education in China 9 (1): 24-41.

Marginson, Simon (2009) 'Open Source Knowledge and University Rankings', Thesis Eleven 96: 9-39.

Mignolo, Walter (2002) 'The Enduring Enchantment: (Or the Epistemic Privilege of Modernity and Where to Go from Here)', The South Atlantic Quarterly 101 (4): 941-942.

Motta, Sara C. (2013) 'Teaching Global and Social Justice as Transgressive Spaces of Possibility', Antipode 45 (1): 80-100.

Nelson, Cary (2011) No University is an Island: Saving Academic Freedom (New York: New York University Press).

Nisbett, Richard (2003) The Geography of Thought: How Asians and Westerners Think Differently... And Why (New York: The Free Press).

Owen, Catherine John Heathershaw and Igor Savin (2018) 'How postcolonial is post-Western IR? Mimicry and mētis in the international politics of Russia and Central Asia', Review of International Studies 44 (2): 283-284.

Oyserman, Daphna and Spike W. S. Lee (2008) 'Does Culture Influence What and How We Think? Effects of Priming Individualism and Collectivism', Psychological Bulletin 134 (2): 311-342.

Polanyi, Michael (1975 [1940]) Contempt of Freedom: Russian Experiment and After (New York: Arno Press).

Redden, Elizabeth (2018) 'Did Trump Call Most Chinese Students Spies?', Inside Higher Ed, 9 August 2018. Available at: https://www.insidehighered.com/news/2018/08/09/politico-reports-trumpcalled-most-chinese-students-us-spies.

Royal Society (2011) 'Knowledge, Networks and Nations: Global Scientific Collaboration in the $21^{\text {st }}$ Century', (London: The Royal Society). Available at: https://royalsociety.org/topicspolicy/projects/knowledge-networks-nations/report/.

Russell Group (2018) 'Links Between China and Russell Group Universities'. Available at: https://www.russellgroup.ac.uk/media/5680/russell-group-universities-links-with-china-january2018.pdf.

Ryan, Janette (2010) 'The "Chinese Learner": Misperceptions and Realities' in Janette Ryan and Gordon Slethaug (eds.) International Education and the Chinese Learner (Hong Kong: University of Hong Kong Press).

Ryan, Janette and Kam Louie (2007) 'False Dichotomy? 'Western' and 'Confucian' Concepts of Scholarship and Learning', Educational Philosophy and Theory 39 (4):404-417 (2007)

Sahlins, Marshall (2015) Confucius Institutes: Academic Malware (Chicago: Prickly Paradigm Press). Said, Edward W. (1994) Culture and Imperialism (London: Chatto \& Windus). 
Santos, Boaventura de Sousa (2014) Epistemologies of the South: Justice Against Epistemicide (Abingdon: Routledge).

Schrecker, Ellen (2010) The Lost Soul of Higher Education: Corporatisation, the Assault on Academic Freedom and the End of the American University (New York: The New Press).

SCMP (2018) 'Top Dutch university cancels plan for China campus "over academic freedom concerns"', South China Morning Post, 31 January 2018. Available at:

https://www.scmp.com/news/china/article/2131286/top-dutch-university-cancels-plan-chinacampus-over-academic-freedom.

SCMP (2017) 'At Beijing book fair, publishers admit to self-censorship to keep texts on Chinese market', South China Morning Post, 24 August 2017. Available at:

https://www.scmp.com/news/china/policies-politics/article/2108095/beijing-book-fair-publishersadmit-self-censorship-keep.

Shambaugh, David (2016) China's Future (Cambridge: Polity Press).

Teichler, Ulrich (2004) 'The Changing Debate on Internationalisation of Higher Education', Higher Education 48: 5-26.

THE (2018) 'Best universities for social science degrees 2019', Times Higher Education, 17 October 2018. Available at: https://www.timeshighereducation.com/student/best-universities/bestuniversities-social-science-degrees.

Tierney, William and Michael Lanford (2014) 'The Question of Academic Freedom: Universal Right or Relative Term?', Frontiers of Education in China 9 (1): 4-23.

Traianou, Anna (2015) 'The erosion of academic freedom in UK Higher Education', Ethics in Science and Environmental Politics, 15 (1): 39-47.

Vázquez, Rolando (2015) 'Decolonial Practices of Learning' in John Friedman, Vicki Haverkate, Barbara Oomen, Eri Park and Marcin Sklad (eds.) Going Glocal in Higher Education: The Theory, Teaching and Measurement of Global Citizenship (Middelberg, NL: University College Roosevelt).

Yang, Rui (2014) 'China's Strategy for the Internationalization of Higher Education: An Overview', Frontiers of Higher Education in China 9 (2): 151-162.

Yang, Yuan (2018) 'Cornell Halts China University Ties over Curbs on Academic Freedom', Financial Times, 30 October 2018. Available at: https://www.ft.com/content/b07c275c-d832-11e8-a85433d6f82e62f8.

Zha, Qiang and Ruth Hayhoe (2014) 'The "Beijing Consensus" and the Chinese Model of the University', Frontiers of Education in China 9 (1): 42-62.

Zhang, Yuehong (2010) 'Chinese journal finds 31\% of submissions plagiarized', Nature 467: 153.

Zhao, Suisheng (2016) 'Xi Jinping's Maoist Revival', Journal of Democracy 27 (3): 83-97. 